War he served with R.E.M.E. and was demobilized in 1947 with the rank of captain. He then studied at Queen's University, Belfast, and graduated with first-class honours both in electrical and in mechanical engineering in 1950. His research will be on the secondary emission coefficients in magnetrons.

\section{Ramsay Memorial Fellowships}

The Ramsay Memorial Fellowships Trustees have made the following awards of new fellowships in chemistry for 1952-53: Mr. D. Clark, a British Fellowship of $£ 500$ a year at the University of Birmingham; Mr. R. F. Webb, a British Fellowship of $£ 500$ a year at the University of Cambridge; Dr. G. S. Trick, a Canadian Fellowship at King's College, London; Mr. Juan Llopis Mari, a Spanish Fellowship at King's College, London; Mr. R. O. Steiner, a Swiss Fellowship at the Imperial College of Science and Technology, London; Mr. David R. Lide, a United States Fellowship at the University of Oxford. The Trustees have renewed the following fellowships for the same year: Mr. L. E. Lyons (British Fellowship) at University College, London; Mr. James Jack (Glasgow Fellowship) at the University of Cambridge; Dr. Serafin Novoa (Spanish Fellowship) at the University of Oxford.

\section{Botanical Society of Bengal: Annual General Meeting and Officers}

THE annual general meeting of the Botanical Society of Bengal was held on April 27 at the Botany Laboratory, Presidency College, Calcutta. Dr. J. C. Sen Gupta, principal of the College, who is also the president of the Society, pointed out in his address that the physiology of plants with which we are at present familiar is a physiology of the plants of the temperate climate of Europe and North America, and he stressed the importance of a thorough research on the physiology of tropical plants. This will also help in future plans for research on improvement of agricultural crops, medicinal plants and other plants of economic importance. He also laid stress on the need for enlarging the scope of study in plant physiology at Indian universities and pointed out the great importance of taking necessary steps for the establishment of an institute of plant physiology in or near Calcutta. The chief guest at the meeting, H.E. Dr. H. C. Mookerjee, spoke on the need of research for the betterment of crop yields and the introduction and synthesis of new fruits, etc.; he also emphasized that there should be more members of the Society, and all of them should undertake co-ordinated research. The following officers of the Society were elected : President, Dr. J. C. Sen Gupta; Vice-Presidents, Dr. K. P. Biswas and Prof. P. C. Sarbadhikari ; Secretary for Foreign Correspondence, Sri A. K. Ghosh ; Councillors, Dr. H. K. Nandi, Dr. S. M. Sircar, Dr. P. N. Bhaduri, Dr. H. L. Chakravorty, Dr. B. K. Kar, Prof. B. K. Mitra and Dr. P. N. Nandi; Editor of Publications, Prof. S. R. Bose; Honorary Secretary, Dr. N. K. Sen (35 Ballygunge Road, Calcutta 19); Honorary Treasurer, Sri P. K. Bose ; and Honorary Librarian, J. Sen.

\section{Symposium on Combusion}

AN international symposium on combustion is to be held at the Massachusetts Institute of Technology during September 1-5. It is expected that about a hundred papers will be presented, from Great Britain, France, Holland, Belgium, Germany, Japan and the United States. Emphasis is being placed on the physical aspects of combustion, particularly wave phenomena and turbulence, treated from both the experimental and theoretical points of view. The complete papers will appear later in a single volume, like that issued after a similar symposium held in 1948. Further information can be obtained from the Summer Session Office, Combustion Symposium Committee, Massachusetts Institute of Technology, Cambridge 39, Massachusetts, or from Prof. Hoyt C. Hottel, professor of fuel engineering at the Institute, who is co-chairman of the symposium.

\section{Forthcoming Congresses associated with Inter- national Scientific Unions}

THE following meetings associated with international scientific unions are taking place in the next few months: the Royal Society, through its British national committees, is the adhering body for Britain to each of the unions, and available information of these congresses may be obtained from the Assistant Secretary of the Royal Society (Burlington House, Piccadilly, London, W.1). Astronomy: Eighth General Assembly of the International Astronomical Union (Rome, September 4-13) ; Geography : Fighth General Assembly of the International Geographical Union (Washington, August 8-15, to coincide with the seventeenth International Geographical Congress); Theoretical and Applied Mechanics : Third General Assembly of the International Union of Theoretical and Applied Mechanics (Istanbul, August $20-28$, to coincide with the seventh International Congress of Applied Mechanics); Scientific Radio : Tenth General Assembly of the International Union of Scientific Radio (Sydney, August 11-23); Analytical Chemistry : First International Congress on Analytical Chemistry (Oxford, September 4-9); meetings of the Analytical Chemistry Section of the International Union of Pure and Applied Chemistry will take place during the period of the Congress; International Council of Scientific Unions: Sixth General Assembly of the International Council of Scientific Unions (Amsterdam, October 1-3).

\section{University of London}

DR. F. L. WARREN, reader in biochemistry in University College, has been appointed to the University chair of biochemistry tenable at London Hospital Medical College. Dr. Eric Neil, senior lecturer in physiology in Middlesex Hospital Medical School, has been appointed to the University readership in physiology tenable at. Middlesex Hospital Medical School. Dr. W. S. Bullough, honorary lecturer in the University of Sheffield, has been appointed to the University chair of zoology tenable at Birkbeck College.

\section{Colonial Service: Recent Appointments}

THE following appointments have recently been made in the Colonial Service : R. B. Allnutt (director of agriculture, Leeward Islands), assistant director of agriculture, Nigeria; R. Aribisala, J. A. Carter, R. F. S. Hainsworth, D. R. E. Jackson, J. O. I. Longe, R. Miller and P. Mulholland (agricultural superintendents, Nigeria), agricultural officers, Nigeria ; E. J. Gregory (senior agricultural officer, Jamaica), deputy director of agriculture, Jamaica; R. B. Jagoe (senior botanist (time scale), Federation of Malaya), senior botanist (superscale), Federation of Malaya; G. B. Kennard (marketing officer, British Guiana), senior field officer, British Guiana; E. W. Leach (director of agriculture, Trinidad), director of 